\title{
Evaluation Of Drug Storage Using FIFO/FEFO Methods In Royal Prima Medan Hospital Pharmacy Installation
}

\author{
Dewi Sri Rezeki ${ }^{1 *}$, Mangatas Silaen ${ }^{2}$, Ermi Girsang ${ }^{3}$, Sri Ramadhani Nasution ${ }^{4}$ \\ 1,2,3,4Public Health Department, Faculty Of Medicine Universitas Prima Indonesia \\ Medan, Indonesia \\ ${ }^{*}$ Corresponding author: \\ Email:drdewisrirezeki23@gmail.com
}

\begin{abstract}
.
Inappropriate drug storage system can cause the drug to break down quickly, drug expiration, stockout and drug stagnation. This study aims to evaluate the storage of drugs using the FIFO and FEFO methods in Royal Prima Medan Hospital Pharmacy Installation Warehouse. This type of research is descriptive qualitative. The research samples were employees of Royal Prima Medan Hospital Pharmacy Installation Warehouse who had worked for \pm 1 year. For the validity and reliability of the data, source triangulation and method triangulation were used. Data analysis in this study used domain analysis. The results of this study indicate that drug storage activities using the FIFO and FEFO methods in Royal Prima Medan Hospital Pharmacy Installation Warehouse have been running well. Although in the implementation of drug storage activities, human resources problems have been found that play a dual role in their duties, problems of miscommunication among human resources and there is still a lack of training on drug storage using the FIFO and FEFO methods. It is hoped that Royal Prima Medan Hospital Pharmacy Installation warehouse will more attention to existing human resources problems.
\end{abstract}

Keywords: Evaluation, Drug Storage, FIFO, FEFO, Pharmacy Warehouse

\section{INTRODUCTION}

The Pharmacy Installation is one of the main revenue centers of the Hospital. Pharmacy installations are the main source of hospital revenue with the purchase of pharmaceutical supplies which absorbs $40-50 \%$ of the hospital's total budget. According to WHO, in some developed countries the cost of spending drugs ranges from $10-15 \%$ of the health budget, such as in Germany $15 \%$ and Japan $19 \%$, while in developing countries this cost is greater, namely $35-66 \%$, for example in Thailand it is 35\%, China $45 \%$ and Mali $66 \%$. Meanwhile in Indonesia, the cost of drugs is $40-50 \%$ of the total operational health services in hospitals. Good drug management is needed because inefficiency in drug management will have a negative impact on the operational costs of health services in hospitals. Drug management is a series of activities that include planning, budgeting, procurement, storage, distribution, control, destruction, recording, reporting, and evaluation of drugs. This study focuses on drug storage in the warehouse of the Hospital Pharmacy Installation [1][2].Drug storage using the FIFO (First in First Out) and FEFO (First Expired First Out) methods is a method of drug storage that has been used widely in various hospital pharmacy installations. The method of storing drugs with FIFO and FEFO in the Hospital Pharmacy Installation Warehouse will not run smoothly without a good, directed and sustainable system. This method is supported by good human resources, budgets, procedures, documents, facilities and infrastructure [1][3].Inappropriate drug storage system can result in many losses, including deterioration of drugs, reduced quality of drugs, expired drugs, stockouts drugs and stagnant drugs. Drug management in Pharmacy Installation of the Eye Hospital of the East Java Community is still not running well as evidenced by the high incidence of stagnant drugs, namely $39 \%$ and $29 \%$ for the incidence of stockout [4].

Whereas in the Regional General Hospital Makassar City the incidence of drug stockout was $19.1 \%$ and drug stagnation was 5.7\%[5]. Research at the Bungoma County Health Service states FEFO method is a preferred inventory control method as it allows for issuance of those medicines that are near to be expired, sparing those with longer expiry dates. This way, losses and wastage through expiry of medicines is prevented.[6] While 
research in department of pharmacy hospital nacional Guido Valadares Dili state that already using the FIFO and FEFO drug storage methods but the expiration and drug damage rates are 20,76\%[7]. The implementation of the Kanban Chip with the FIFO method as control of the flow of goods in and out results in relatively more controlled stock information on incoming and outgoing goods.[8] While the warehouse inventory information system using the FEFO method at Indomedika Pharmacy Sukabumi is proven can carry out transactions effectively and efficiently [9].The FEFO method is applied in the Pharmacy information system at Muhammadiyah Hospital Palembang, it is hoped that there will be no more accumulation of drugs and drugs with shorter expiration dates than drugs with longer expiration dates can be issued in order [10]. Meanwhile, research on the analysis of drug logistics management at the Sam Ratulangi Tondano Regional General Hospital Pharmacy Installation concluded that drug logistics management at the Sam Ratulangi Tondano Hospital Pharmacy Installation had not been running in accordance with the pharmaceutical service standards at the hospital that had been set due to problems with warehouse facilities pharmacy so that there is still accumulation of drugs [11].The storage of drugs in the Pharmacy Installation of the UPT Eye Hospital for the East Java Community is not going well.

The process of controlling temperature and humidity has not been carried out every day so that the temperature and humidity measurement documents are less accurate due to the limited number of officers who handle storage warehouses [4]. Another study at the Pharmacy warehouse of the Regional General Hospital Sekayu City, Musi Banyuasin Regency, Palembang stated that the management of drug supplies in the pharmacy warehouse at the Sekayu City Hospital Pharmacy warehouse was not yet effective. This can be seen from the lack of Human Resources, inadequate storage facilities and storage space and insufficient budget, inaccurate planning and inadequate storage space, while the output still contains expired and damaged drugs [12]. There is no research on evaluating drug storage using the FIFO and FEFO methods in Indonesia.Royal Prima Medan General Hospital has implemented the FIFO and FEFO methods in the drug storage system in Pharmacy Installation Warehouse. Based on the introduction described above, there are no studies evaluating drug storage using the FIFO and FEFO methods so research is interested in evaluating drug storage using the FIFO and FEFO methods through Human Resources, budgets, procedures, facilities and infrastructure documents in Royal Prima Medan Hospital Pharmacy Installation warehouse so as to improve the drug storage management system.

\section{METHOD}

\section{Research Type and Design}

This research design is qualitative descriptive study design to evaluate drug storage using the FIFO and FEFO methods. Primary data in this study were obtained based on the results of interviews with respondents and triangulation, while secondary data was obtained from the results of 2020 document tracing. To anticipate the accuracy of the information, triangulation was carried out.

\section{Location and Time of Research}

This research was conducted at Royal Prima Medan Hospital Pharmacy Installation warehouse at Jalan Ayahanda No.68A, Medan City, North Sumatra. The research was carried out from June to October 2020, with stages starting from submitting titles and continuing research from November to December 2020.

Population and Research Sample

The population used in this study were drug management staff and drug storage data in the Royal Prima Medan Hospital Pharmacy Installation warehouse in 2020.The samples in this study were taken by purposive sampling. The selected informants have worked for \pm 1 year at the Royal Prima Medan Hospital. The samples are the head of the Pharmacy Installation (1 person), the head of the Pharmacy Installation warehouse (1 person), the Pharmacy Installation warehouse executive staff $(1$ person) and the Pharmacy Installation warehouse administrative staff (1 person).

\section{Data Collection Instruments}

The instruments used in this study included interview guides, document review guidelines, observation sheets, writing instruments, laptops, cameras and recording devices. Data collection was carried out through in- 
depth interviews, observation and review of documents in the warehouse of Royal Prima Medan Hospital Pharmacy Installation

\section{Validity and Reliability}

The data triangulation used in this research is source triangulation and method triangulation. Triangulate sources by examining and adjusting the results of in-depth interviews with several different informants. Meanwhile, the triangulation method is by adjusting the results of in-depth interviews to observation and document review. Triangulation is carried out to obtain correct, accurate and reliable data

\section{Data analysis}

Data analysis carried out in this study used domain analysis.

\section{Ethical Approval}

Ethical Approval This study has been declared ethical by the Ethics Commission of the Faculty of Medicine, Prima Indonesia University with letter number 006 // KEPK / UNPRI / XII / 2020. Before filling in an in-depth interview, informed consent was given to the respondents as consent to participate in this study.

\section{RESULTS AND DISCUSSION}

Human Resources in the Royal Prima Medan Hospital Pharmacy Installation warehouse have met the existing standard needs and have a fairly good performance in the implementation of drug storage activities using the FIFO and FEFO methods. Constraints are found that there is a dual role for employees in carrying out their duties. This happens when the number of drug distributors who come in is added by the large number of requests from the pharmaceutical service department. Having a dual role in the job makes it unclear the person responsible for medical devices and drugs in the Pharmacy Installation. In addition, job descriptions from the medical device and drug sections that have not been made, socialized, and approved by the hospital are one of the factors causing the problem of ineffectiveness and efficiency of pharmaceutical supplies [13].In addition, it was found that there was a problem of miscommunication among Human Resources in the warehouse of the Royal Prima Medan Hospital Pharmacy Installation warehouse. This miscommunication problem is such as wrong in delivering directions, forgetting to convey directions to other employees and so on. The final problem is the lack of training regarding the storage of drugs using the FIFO and FEFO methods. This of course can affect the knowledge and skills of employees. Training can increase the knowledge and skills of employees in carrying out their duties so that drug management can be more optimal [14].Royal Prima Medan Hospital does not provide a special budget for drug storage activities using the FIFO and FEFO methods. As for warehouse needs, the Pharmacy Installation warehouse officer asked the general logistics department of the Royal Prima Medan Hospital, so that the budgeting was included in the general department budgeting, not the drug management budget in the pharmacy warehouse[12][15]. The results were in line with the Guidelines for Drug Management made by the Directorate General of Pharmacy and Medical Devices (2010).

Royal Prima Medan Hospital Pharmacy Installation warehouse already has Standard Operating Procedures (SOP) regarding storage activities for drugs and medical devices. However, there is no Standard Operating Procedure for storing drugs using the FIFO and FEFO methods even though the FIFO and FEFO methods have been implemented in the storage activities. There are no obstacles in implementing the existing Standard Operating Procedures.The Pharmacy and Therapy Committee prepares a Hospital formulary and makes a Standard Operating Procedure in accordance with the Pharmaceutical Service Standards in Hospitals as stipulated in the Minister of Health Regulation Number 58 of 2014[10]. Standard Operating Procedure is made in an effort to limit employee behavior and as a regulation written for the smooth management of drug supply activities at the pharmacy[16]. Standard Operating Procedures have been made concise and clear so that they can be easily understood by officers[12].Royal Prima Medan Hospital Pharmacy Installation warehouse already has complete recording and reporting documents, both using computers and manually. Recording and reporting documents that use computers such as inputting incoming goods invoices, drug mutations, drug stocks, slow moving drug lists, expired drug lists and several other activities. Some recording and reporting activities are still done manually. Recording and reporting are done manually, such as temperature forms, order letters, empty medical equipment lists, goods picker books and adjustment books. Drug Storage Recording Documents in accordance with the 
Regulation of the Minister of Health of the Republic of Indonesia Number 72 of 2016 consist of LPLPO (Drug Usage Report and Request Sheet), stock cards, drug receipt and dispensing books, damaged / expired drug records and drug mutation reports.In the process of recording manually, errors often occur. There is often a loss of data on the recording of goods (drugs), and the production of reports is hampered.

Lack of accuracy in recording inventory of goods (drugs) which hinders the process of sending goods. In the future, it is hoped that recording and reporting will use computers[17]. The use of a computer system for recording and reporting in the Pharmacy Installation warehouse is useful for providing fast, accurate inventory reports, information on drugs that will be expired, minimum drug stock information and a more secure level of data security[18].The facilities and infrastructure in Royal Prima Medan Hospital Pharmacy Installation warehouse are sufficient. The facilities and infrastructure in the Royal Prima Medan Hospital Pharmacy Installation warehouse can be seen in table I. Based on the Regulation of the Minister of Health Number 72 of 2016, that the implementation of Pharmaceutical Services in Hospitals must be supported by facilities and infrastructure that meet the provisions and applicable pharmaceutical legislation. The facilities and infrastructure are in the form of adequate space facilities in terms of quality and quantity in order to support the function and process of pharmaceutical services, ensure a safe working environment for officers and facilitate the hospital communication system, both main facilities and supporting facilities in service activities in the Pharmacy Installation warehouse. Meanwhile, equipment facilities must meet the requirements, especially for compounding and preparation equipment for both sterile and non-sterile preparations and liquid drug preparations for external or internal medicine. Equipment facilities must be guaranteed to be sensitive to measurement and meet the requirements and calibration for certain equipment every year[19]. The available facilities and infrastructure are sufficient and make it easy for officers to store drugs, such as easy placement of drugs with FIFO/ FEFO description and easy separation of drugs based on their preparation[20].

\section{Facilities And Infrastructure In Royal Prima Medan Hospital Pharmacy Installation Warehouse}

\begin{tabular}{|c|c|c|c|c|}
\hline \multirow[t]{2}{*}{ No } & \multirow[t]{2}{*}{ Observation Statement } & \multicolumn{2}{|c|}{ Result } & \multirow[t]{2}{*}{ Infor mation } \\
\hline & & Yes & $\mathrm{No}$ & \\
\hline 1 & $\begin{array}{l}\text { Availability of room / office } \\
\text { for the head of the Pharmacy } \\
\text { Installation }\end{array}$ & $\mathrm{V}$ & & \\
\hline 2 & $\begin{array}{l}\text { Availability of room / office } \\
\text { for the head of warehouse }\end{array}$ & V & & \\
\hline 3 & $\begin{array}{l}\text { Separate room / office with } \\
\text { medicine warehouse }\end{array}$ & & V & \\
\hline 4 & There is a computer & $\mathrm{V}$ & & \\
\hline 5 & $\begin{array}{l}\text { There are tables, chairs, } \\
\text { cupboards, in the room / } \\
\text { office }\end{array}$ & V & & \\
\hline 6 & $\begin{array}{l}\text { There are stationery in the } \\
\text { room / office }\end{array}$ & V & & \\
\hline 7 & $\begin{array}{l}\text { There are supported phones } \\
\text { available }\end{array}$ & $\mathrm{V}$ & & \\
\hline 8 & Air conditioning is available & V & & \\
\hline 9 & $\begin{array}{l}\text { A fire extinguisher is } \\
\text { available }\end{array}$ & V & & \\
\hline 10 & $\begin{array}{l}\text { There are measuring and } \\
\text { temperature control tools that } \\
\text { function properly }\end{array}$ & V & & \\
\hline 11 & $\begin{array}{l}\text { There is a medicine receipt } \\
\text { diary }\end{array}$ & V & & Using a computer \\
\hline 12 & $\begin{array}{l}\text { There is a medicine } \\
\text { dispensing diary }\end{array}$ & V & & Using a computer \\
\hline 13 & $\begin{array}{l}\text { There is an expired drug } \\
\text { document }\end{array}$ & $\mathrm{V}$ & & Using a computer \\
\hline 14 & $\begin{array}{l}\text { There is a medicine storage } \\
\text { shelf / cupboard that is clean } \\
\text { and not placed directly on the }\end{array}$ & V & & \\
\hline
\end{tabular}




\begin{tabular}{|c|c|c|c|c|}
\hline & floor & & & \\
\hline 15 & $\begin{array}{l}\text { Availability of a special } \\
\text { cupboard that is locked for } \\
\text { storage of Narcotics and } \\
\text { Psychotropics }\end{array}$ & V & & \\
\hline 16 & $\begin{array}{l}\text { There is a refrigerator to store } \\
\text { certain types of drugs that } \\
\text { require cold temperatures }\end{array}$ & V & & \\
\hline 17 & $\begin{array}{l}\text { There is a special cupboard } \\
\text { for drugs } \\
\text { damaged and expired }\end{array}$ & $\mathrm{V}$ & & \\
\hline 18 & $\begin{array}{l}\text { Shelves / cabinets are not } \\
\text { directly attached to the floor }\end{array}$ & $\mathrm{V}$ & & \\
\hline 19 & $\begin{array}{l}\text { Shelves / cabinets are not } \\
\text { directly attached to the floor }\end{array}$ & $\mathrm{V}$ & & \\
\hline 20 & $\begin{array}{l}\text { Availability of tools for } \\
\text { transferring drugs in the } \\
\text { warehouse }\end{array}$ & $\mathrm{V}$ & & \\
\hline 21 & $\begin{array}{l}\text { Medicine stock card is } \\
\text { available to provide } \\
\text { information on the storage } \\
\text { shelf / cupboard }\end{array}$ & & V & Using a computer \\
\hline 22 & $\begin{array}{l}\text { There is a color label / mark } \\
\text { that distinguishes the first } \\
\text { drug entered }\end{array}$ & $\mathrm{V}$ & & \\
\hline 23 & $\begin{array}{l}\text { There is a color label / mark } \\
\text { that distinguishes drugs that } \\
\text { are approaching expiration }\end{array}$ & $\mathrm{V}$ & & \\
\hline 24 & $\begin{array}{l}\text { Availability of plinth for } \\
\text { goods }\end{array}$ & $\mathrm{V}$ & & \\
\hline 25 & $\begin{array}{l}\text { The distance between plinth } \\
\text { and floor (minimum } 10 \\
\text { centimeters) }\end{array}$ & $\mathrm{V}$ & & \\
\hline 26 & $\begin{array}{l}\text { The distance between plinth } \\
\text { and wall (minimum } 30 \\
\text { centimeters) }\end{array}$ & $\mathrm{V}$ & & \\
\hline 27 & $\begin{array}{l}\text { The door to the room is made } \\
\text { in layers }\end{array}$ & $\mathrm{V}$ & & \\
\hline 28 & $\begin{array}{l}\text { The warehouse has a safety } \\
\text { lock and is locked when there } \\
\text { is no activity }\end{array}$ & $\mathrm{V}$ & & \\
\hline 29 & $\begin{array}{l}\text { There is a double made room } \\
\text { key }\end{array}$ & $\mathrm{V}$ & & \\
\hline 30 & $\begin{array}{l}\text { The warehouse has } \\
\text { windows that are trellised }\end{array}$ & & V & \\
\hline 31 & $\begin{array}{l}\text { The warehouse has adequate } \\
\text { ventilation, air circulation } \\
\text { and lighting }\end{array}$ & $\mathrm{V}$ & & \\
\hline 32 & $\begin{array}{l}\text { The warehouse area is } \\
\text { adequate and safe for the } \\
\text { movement of officers }\end{array}$ & V & & $\begin{array}{l}\text { Warehouse area }= \\
8 \times 6 \text { square meter }\end{array}$ \\
\hline 33 & $\begin{array}{l}\text { The roof and walls of the } \\
\text { warehouse are in good } \\
\text { condition and are not leaking }\end{array}$ & $\mathrm{V}$ & & \\
\hline 34 & $\begin{array}{l}\text { The floor is not ground and is } \\
\text { in a clean state }\end{array}$ & $\mathrm{V}$ & & \\
\hline 35 & $\begin{array}{l}\text { The warehouse is free from } \\
\text { pests that have the potential } \\
\text { to damage the quality of } \\
\text { medicines such as ants, }\end{array}$ & $\mathrm{V}$ & & \\
\hline
\end{tabular}




\begin{tabular}{|l|l|l|l|l|}
\hline 36 & cockroaches, rats and others & & & \\
$\begin{array}{l}\text { There is a provision that it is } \\
\text { prohibited to enter drug } \\
\text { storage areas other than } \\
\text { officers }\end{array}$ & $\mathrm{V}$ & & \\
\hline
\end{tabular}

Source: The results of observations of the Royal Prima Medan Hospital Pharmacy Installation warehouse in 2020

Drug storage using the FIFO and FEFO methods has been widely used in various Hospital Pharmacy Installations[12][21]. This method certainly aims to make the drug storage system in the warehouse better and more systematic. Based on the results of the study, it was found that the storage of drugs in Royal Prima Medan Hospital Pharmacy Installation warehouse was prepared based on the FIFO and FEFO methods.Drug storage methods can be carried out based on therapeutic class, dosage form, types of pharmaceutical preparations, medical devices, and medical consumables arranged alphabetically by applying the principles of FEFO and FIFO accompanied by an information system. Management[1].Drug storage using the FIFO method has been running well in Royal Prima Medan Hospital Pharmacy Installation warehouse. The first drug comes from the distributor, the drug will be received by the Pharmacy Installation warehouse employee then the medicine will be arranged in a shelf / cupboard based on the order of entry[16][17]. In this case, no significant constraints were found in the FIFO method of storing drugs.Drug storage using the FEFO method has been running well in the pharmacy installation Royal Prima Medan Hospital Pharmacy Installation warehouse. Medicines that come from drug distributors will be received by the Pharmacy Installation warehouse employees then the drugs will be arranged in a shelf / cupboard based on the expired date.

Drugs with a shorter expiration date will be issued in advance of drugs with a longer expiration date[11][22]. Similar to the method of storing drugs using the FIFO method, there are no significant obstacles found in the method of storing drugs using the FEFO method. These two methods of drug storage, namely the method of storing drugs with the FIFO method and the FEFO method are commonly applied in Royal Prima Medan Hospital Pharmacy Installation warehouse. The two methods are inseparable. This method is complementary to one another in supporting drug storage activities.Drug availability is the main output in drug storage activities in Royal Prima Medan Hospital Pharmacy Installation warehouse. In maintaining the availability of drugs, the Pharmacy Installation Warehouse must further improve the drug management system. The purpose of drug supply management is the availability of drugs in the right amount (right amount, right type and time), adequate quality at the lowest possible cost and an inventory that is not compromised by damage, waste, unauthorized use, theft and improper depreciation. Based on the research results, it was found that the incidence of stockout in 2019 was $1.7 \%$, while in 2020 it was $2.3 \%$. The incidence of drug stockout has increased from the previous year. The incidence of stagnation in 2019 was $0.9 \%$, while in 2020 it was $1.4 \%$. The incidence of drug stagnation has increased from the previous year. Meanwhile, the incidence of expired drugs in 2019 was $1.1 \%$ and in 2020 was $0.9 \%$. The incidence of expired drugs has decreased from the previous year. This can be seen in tables III, IV and V below.

Table 2. Total Percentage Of Drug Stockout In Royal Prima Medan Hospital Pharmacy Installation Warehouse From July To December 2020

\begin{tabular}{|l|l|l|l|}
\hline Year & $\begin{array}{l}\text { Drugs that have } \\
\text { stockouts (item) }\end{array}$ & $\begin{array}{l}\text { Percentage } \\
(\%)\end{array}$ & Information \\
\hline 2019 & 30 item & $1,7(\%)$ & $\begin{array}{l}\text { There is an increase in the } \\
\text { percentage of drugs in } \\
2020\end{array}$ \\
\hline 2020 & 40 item & $2,3(\%)$ &
\end{tabular}

Source: Results of Document Review of Royal Prima Medan Hospital Pharmacy Installation warehouse in 2020

Table 3.Total Percentage Of Slow Moving Drug In Royal Prima Medan Hospital

Pharmacy Installation Warehouse From July To December 2020

\begin{tabular}{|c|l|c|c|}
\hline Year & Drugs that are & Percentage & Information \\
\hline & $\begin{array}{l}\text { experiencing slow } \\
\text { moving (item) }\end{array}$ & $(\%)$ & \\
\hline
\end{tabular}




\begin{tabular}{|l|l|l|l|}
\hline 2019 & 16 item & $0,9(\%)$ & $\begin{array}{l}\text { There is an increase in the } \\
\text { percentage of drugs that are } \\
\text { experiencing slow moving in } 2020\end{array}$ \\
\hline 2020 & 25 item & $1,4(\%)$ &
\end{tabular}

Source: Results of Document Review of Royal Prima Medan Hospital Pharmacy Installation warehouse in 2020

Table 4. Total Percentage Of Expired Drug In Royal Prima Medan Hospital Pharmacy

Installation Warehouse From July To December 2020

\begin{tabular}{|l|l|l|l|}
\hline Year & Expired drugs (item) & Percentage (\%) & Information \\
\hline 2019 & 20 item & $1,1(\%)$ & $\begin{array}{l}\text { There has been a decrease in } \\
\text { the percentage of drugs that } \\
\text { have expired in 2020 }\end{array}$ \\
\hline 2020 & 15 item & $0,9(\%)$ &
\end{tabular}

Source: Results of Document Review of Royal Prima Medan Hospital Pharmacy Installation warehouse in 2020

Anggraini's research (2018) found that the value of damaged and expired drugs in the Pharmacy Installation of the Rokan Hulu Regency Health Service in 2018 was $0.33 \%$. The percentage of the value of damaged and expired drugs is still acceptable if the value is below $1 \%$. The value of damaged and expired drugs reflects a good distribution system and a good planning system, as well as routine quality observations in drug storage. According to Winasari's (2015) study of the causes of patent drug stock vacancies and efforts to control them in the medical warehouse of the Bekasi City Hospital Pharmacy Installation in the first quarter of 2015, the results showed that the description of the causes of patent drug vacancies and their control efforts in the medical warehouse of the Bekasi City Hospital Pharmacy Installation in I in 2015, it was found that there were 6 types of drugs in the January - March 2015 period at the Bekasi City Hospital pharmacy warehouse. The percentage of expired drugs in the hospital pharmacy warehouse is $0.8 \%$. Research on Hadidah (2016) about the factors causing the incidence of stagnation and stockout in the pharmaceutical installation of the UPT Eye Hospital for the East Java Community showed that drug management at the UPT Pharmacy Installation of the East Java Community Eye Hospital was still not going well as evidenced by a sufficient number of stagnant drugs. high, namely $39 \%$ and $29 \%$ for the event of stockout.

\section{RESEARCH LIMITATION}

A limitation in this study is that in-depth interviews are conducted during working hours/service hours so that respondents sometimes do not focus on answering questions.

\section{CONCLUSION}

The storage of drugs using the FIFO and FEFO methods in Royal Prima Medan Hospital Pharmacy Installation warehouse is already running well. Although in the implementation of drug storage activities, Human Resources problems have been found that play a dual role in their duties, problems of miscommunication among Human Resources and there is still a lack of training on drug storage using the FIFO and FEFO methods. It is hoped that the Royal Prima Medan Hospital Pharmacy Installation warehouse will pay more attention to Human Resources problems.

\section{ACKNOWLEDGMENT}

The author would like to thank various parties who have provided assistance, encouragement and guidance in the preparation of this article.

\section{REFERENCES}

[1] [Kementrian Kesehatan Republik Indonesia, Regulation Of The Minister Of Health Of The Republic of Indonesia Number 72 of 2016 Concerning Pharmaceutical Service Standards (Peraturan Menteri Kesehatan Republik Indonesia Nomor 72 Tahun 2016 Tentang Standar Pelayanan Kefarmasian) no.3 May. Indonesia, 2017, pp. 31-48. 
[2] Kementerian Kesehatan Republik Indonesia, Minister Of Health Regulation No. 3 Of 2020Concerning Hospital Classification And Licensing (Peraturan Menteri Kesehatan No 3 Tahun 2020 Tentang Klasifikasi Dan Perizinan Rumah Sakit). Indonesia., no. 3, pp. 1-80, 2020.

[3] Kementerian Kesehatan Republik Indonesia, Regulation Of The Minister Of Health Of The Republic Of Indonesia Number 58 Of 2014 Concerning Pharmaceutical Service Standards In Hospitals (Peraturan Menteri Kesehatan Republik Indonesia Nomor 58 Tahun 2014 Tentang Standar Pelayanan Kefarmasian Di Rumah Sakit). Indonesia, 2014.

[4] Hadidah, S.I, "Factors Causing Stagnant And Stockout Events In The Pharmacy Installation Of The UPT Eye Hospital, East Java Community (Faktor Penyebab Kejadian Stagnant Dan Stockout Di Instalasi Farmasi UPT Rumah Sakit Mata Masyarakat Jawa Timur)" vol. 26, no. 4, pp. 551-556, 2016.

[5] Triyuliandini,M.A, "Qualitative Study Of Drug Stockout And Stagnant In The Pharmacy Installation Of Hospital, Makassar City Region (Studi Kualitatif Stockout Dan Stagnant Obat Di Instalasi Farmasi Rumah Sakit Uumu Daerah Kota Makasar)" Universitas Hasanudin, 2017.

[6] Barasa et al, "Influence Of Inventory Management Practices On Availability Of Medicines In Public Health Facilities In Bungoma County, Kenya," Int. J. Acad. Res. Dev., vol. 3, no. 6, pp. 53-60, 2018.

[7] Martins et al, "Drug Management Analysis in the Department of Pharmacy Hospital Nacional Guido Valadares Dili Timor Leste 2017," Int. J. Recent Acad. Res., vol. 01, no. 06, pp. 226-230, 2019.

[8] Prihartini,D, " The Flow Of Goods In And Out With The First In First Out (FIFO) Method Case Study At PT. Fukoku Industries Indonesia (Alur Keluar Masuk Barang Dengan Metode First In First Out ( FIFO ) Studi Kasus di PT . Fukoku Industries Indonesia)" Presiden University, 2018.

[9] Sembiring,F, "Application of the First Expired First Out (FEFO) Method In The Warehouse Information System (Penerapan Metode First Expired First Out (FEFO) Pada Sistem Informasi Gudang)" Integr. (Information Tecknology Vocat. Educ., vol. 1, no. 2, pp. 19-25, 2019.

[10] Malinggas,N.E.R, "Analysis of Drug Logistics Management At The Pharmacy Installation Of The Regional Hospital of DR Sam Ratulangi Tondano (Analisis Manajemen Logistik Obat di Instalasi Farmasi Rumah Sakit Daerah DR Sam Ratulangi Tondano)" Jikmu, vol. 5, no. 2, pp. 448-460, 2015.

[11] Purwaningtias,F, "Analysis of Drug Logistics Management At The Pharmacy Installation Of The Regional Hospital Of DR Sam Ratulangi Tondano (Sistem Informasi Apotek Menggunakan Metode First Expiry First Out (FEFO) Pada Rumah Sakit Muhammadiyah Palembang)" vol. 2, no. 1, 2016.

[12] M. Badaruddin, "Overview Of Drug Inventory Management In The Pharmacy Warehouse Of The Regional General Hospital Of Sekayu City, Musi Banyuasin Regency, Palembang In 2015 (Gambaran Pengelolaan Persediaan Obat Di Gudang Farmasi Rumah Sakit Umum Daerah Kota Sekayu Kabupaten Musi Banyuasin Palembang Tahun 2015)" 2015.

[13] Yudiansyah dkk, "Increasing the Effectiveness And Efficiency Of Pharmaceutical Supplies In the RSIG Operating Room Installation (Peningkatan Efektifitas Dan Efisiensi Perbekalan Farmasi Di Instalasi Kamar Operasi RSIG)" no. 14, pp. 63-65, 2018.

[14] Hilmawati, Chotimah,I and Dwimawati, E "Analysis Of Drug Logistics Management At Cipayung Health Center, Depok City, West Java Province In 2019 (Analisis Manajemen Logistik Obat Di Puskesmas Cipayung Kota Depok Provinsi Jawa Barat Tahun 2019 Pendahuluan Metode)" vol. 3, no. 4, 2020.

[15] Faturrahmi, "Drug Logistics Management At The Pharmacy Installation Of Dr. RSUP. Wahidin Sudirohusodo Makassar (Manajemen Pengelolaan Logistik Obat Di Instalasi Farmasi RSUP Dr. Wahidin Sudirohusodo Makasar)" UIN Alaudun Makasar, 2019.

[16] Maruf, J.M "Analysis Of Internal Control Over Drug Inventory In Public Sector Organizations At Bahu Community Health Center (Analisis Pengendalian Internal Atas Persediaan Obat Pada Organisasi Sektor Publik Di Puskesmas Bahu)" J. EMBA J. Ris. Ekon. Manajemen, Bisnis dan Akunt., vol. 7, no. 3, pp. 3099-3108, 2019.

[17] Eskawati,F and Nugraha, R "Study Of Inventory Information System Using The FIFO Method At The Sukabumi District Pharmacy Warehouse (Kajian Sistem Informasi Persediaan Barang Menggunakan Metode FIFO Pada Gudang Farmasi Kabupaten Sukabumi)" Konf. Nas. Ilmu Sos. Teknol., pp. 175-180, 2014.

[18] Kristinugraini dkk, "Thesis Journal of Drug Inventory Information Systems Using the FIFO Method At The Mugi Waras Pharmacy Semarang Based On The Client Server (Jurnal Skripsi Sistem Informasi Inventory Obat Menggunakan Metode FIFO Pada Apotik Mugi Waras Semarang Berbasis Clien Server)" 2014. 
[19] Purnawiarti,N "Evaluation Of Pharmaceutical Storage System In Pharmaceutical Logistics Of General Hospital Of Aminah BlitaR (Evaluation Of Pharmaceutical Storage System In Pharmaceutical Logistic Of General Hospital Of Aminah Blitar)" ,2015.

[20] Syahputra,A "Overview of Drug Storage in UPTD Pharmacy Warehouse Langkat District Health Office (Gambaran Penyimpanan Obat Di UPTD Gudang Farmasi Dinas Kesehatan Kabupaten Langkat)",Institut Kesehatan Helvetia, 2019.

[21] Mulalinda dkk, "Overview Drug Storage In The Drug Warehouse Of The Pharmacy Installation Of Sawang Of Sitaro District Hospital," vol. 9, no. November, 2020.

[22] Alfin et al, "Drug Inventory Management Application Using the FEFO Method, Case Study: Upt Puskesmas Kujangsari, Bandung (Aplikasi Pengelolaan Persediaan Obat Menggunakan Metode FEFO, studi Kasus: Upt Puskesmas Kujangsari, Bandung)" eProceedings ..., vol. 5, no. 3, pp. 2682-2687, 2019. 